\title{
Diverse responses for some growth biostimulants on some morphological, physiological, chemical, anatomical and yield characteristics of tomato plant (Lycopersicon esculentum Mill)
}

\author{
El-Emary F.A. ${ }^{a}$, Abd El-Aal M.M. ${ }^{\text {* }}$ \\ ${ }^{a}$ Agricultural Botany Department, Faculty of Agriculture, Al-Azhar University (Assiut Branch), 71524 Assiut, Egypt \\ ${ }^{b}$ Agricultural Botany Department, Faculty of Agriculture, Benha University, Moshtohor, Toukh, Qalyoubia, 13736, Egypt
}

\begin{abstract}
Two field experiments were carried at the Experimental Farm Station of The Faculty of Agriculture, Benha University, Qlubia governorate and Agricultural Botany Department, Faculty of Agriculture, Al-Azhar University (Assiut Branch), Assiut governorate, Egypt, during two successive summer seasons of 2016 and 2017. The aim of this work was to study the effect of foliar application with Arginine at $25,50 \mathrm{mgl}^{-1}$ and Tryptophan at 50,100 mgl${ }^{-1}$ as well as Milagrow at 50 and 100 $\mathrm{mgl}^{-1}$ treatments comparing to the control on morphological, physiological, chemical, anatomical, flowering and yield characteristics of tomato plant. The experiment was performed as a randomized complete block design with four replicates. Different vegetative growth characteristics of plant samples were taken i.e., plant length, stem diameter, number of branches plant $^{-1}$, number of leaves plant ${ }^{-1}$, stem fresh weight plant ${ }^{-1}$, leaves fresh weight plant ${ }^{-1}$, stem dry weight plant ${ }^{-1}$, leaves dry weight plant $^{-1}$ and total leaf area plant ${ }^{-1}$. Photosynthetic pigments in the leaves i.e., Chlorophyll A, B, A+B and Carotenoids $\mathrm{mg} \mathrm{g}^{-1}$ F.Wt., phytohormones i.e., Gibberellins, Auxins, Cytokinins and total promoters as well as Salicylic acid and Abscisic acid content. Anatomical characteristics of tomato plant leaf i.e., thickness of upper epidermis tissue, lower epidermis, palisade tissue, spongy tissue, blade, phloem tissue, xylem tissue, No. of xylem rows, widest of M. xylem vessel, length of vascular bundle, width of vascular bundle and thickness of leaf midrib. Anatomical stem characteristics i.e., thickness of epidermis tissue, collenchyma layers, parenchyma layers, phloem tissue, cambial tissue, xylem tissue, No. of xylem rows vascular cylinder ${ }^{-1}$, No. of xylem vessels row $^{-1}$, widest of M. xylem vessel, thickness of parenchymamatous pith and stem diameter. From these results we can conclude that, the beast treatment was Milagrow at $50 \mathrm{mgl}^{-1} \mathrm{flowed}^{\mathrm{by}}$ Arginine at $50 \mathrm{mgl}^{-1}$ comparing with the control and other applied biostimulant treatments during the both seasons. On the other side, the treatment with Tryptophan, recorded low values, especially at $50 \mathrm{mgl}^{-1}$ comparing with the other biostimulants. At the same time Milagro at $50 \mathrm{mgl}^{-1}$ which recorded the highest values for early yield $(\mathrm{g})$ plant ${ }^{-1}(731.62)$, total fruits No. plant ${ }^{-1}(29.74)$, fruit setting \% (37.19), total yield plant ${ }^{-1}(1.94 \mathrm{~kg})$, fruit fresh weight fruit ${ }^{-1}(67.38 \mathrm{~g})$ and fruit dry weight fruit ${ }^{-1}(3.14 \mathrm{~g})$. The highest values for nitrogen, crude protein, total carbohydrates, total soluble solids and Vitamin $\mathrm{C} \mathrm{mg} 100^{-1} \mathrm{~cm} 3$ juice was recorded with Milagrow at $50 \mathrm{mgl}^{-1}$. On the contrast, the same treatment was recorded low values for phosphorus, potassium and total acidity comparing with the other treatments during both seasons. The negative correlation was found among nitrogen, crude protein, total carbohydrates, total soluble solid and vitamin $\mathrm{C} \mathrm{mg}$ $100^{-1} \mathrm{~cm}^{3}$ juice with phosphorus, potassium and total acidity. From these results can conclude that, the beast treatment was Milagrow at $50 \mathrm{mgl}^{-1}$ flowed by Arginine at $50 \mathrm{mgl}^{-1}$ comparing with the control during the both seasons. On the other side, the treatment with Tryptophan, recorded low values, especially at $50 \mathrm{mgl}^{-1}$ comparing with the other applied biostimulants. Finally, the leaf and stem anatomical characters indicated that Milagrow was the beast treatment for enhancement the diameter of xylem vessel in the stem and No. of xylem rows in the leaf and stem especially at $50 \mathrm{mgl}^{-1}$ as well as increasing the thickness of leaf lamina and midrib especially at $100 \mathrm{mgl}^{-1}$, subsequently increasing the mineral elements transport and photosynthetic rate. Moreover, increasing yield and may be caused the tolerance to an adverse conditions especially high temperature for tomato genotypes during summer season.
\end{abstract}

Keywords: tomato, arginine, tryptophan, milagrow, anatomical characteristics, photosynthetic pigments, yield and quality.

* Corresponding author: Abd El-Aal M.M

E-mail address: mohamed.abdelal@ fagr.bu.edu.eg 


\section{Introduction}

Tomato (Lycopersicon esculentum Mill) is one of the most popular members of Solanaceae family and considered a major vegetable crop in several parts of the world including Egypt. Tomato is used in many forms i.e., fresh salad, cooked food, ketchup, paste and so on. It have essential roles in human nutrition since, it is a rich source of lycopene, minerals and organic acids as well as vitamins i.e., ascorbic acid and $\beta$ carotene which are considered as antioxidants and promoting good health (Wilcox et al., 2003). Lack of tolerance in most tomato cultivars for high temperature is a major limitation for growing in many regions, which the temperature during part of the growing season, even for short period, reaches or higher than $38^{\circ} \mathrm{C}$. High temperature has an adversely effects on tomato vegetative and reproductive growth as well as reducing yield and fruit quality characteristics. Heat stress affects many biochemical and physiological processes finally, leading to non-uniform growth and reduction of tomato yield or even completely tomato cropping failure (Adil et al., 2004, Saeed et al., 2007, Pressman et al., 2002). In order to address food insecurity for increasing population at the national level, it is necessary to maximize yield per unit area per unit farm input. Plant bio regulators represent one area of research for increasing crop productivity as well as water and fertilizers use efficiency and then profitability (Pelt and Popham, 2006). Using the naturally occurring substances such amino acids for enhancing plant growth characteristics was concluded by Abou Dahab and Abd El-Aziz (2006). These growth naturally occurring substances derived from plant and seaweed have not detrimental effects on human being and animals as well as the environment. Using amino acids as a precursor for plant growth promoters is an approach for minimizing the stress effects on plant growth and productivity. L-Tryptophan is a common precursor of plant hormone (auxin) that affects many plant physiological processes after uptake directly or after transforming to auxin (Rai, 2002). L-tryptophan acts as an osmolyte, regulator of ion transport, modulates opening of stomata. Moreover, pathway of tryptophan is playing a defensive role in plant (Hussein et al., 2014). El-Badawy and Abd El-Aal (2013) indicated that foliar spray of mango plant with tryptophan enhanced most of the morphological, physiological and leaf anatomical features. Abd El-Aal and Eid (2018) found that foliar application with amino acids at $4 \mathrm{ml}^{-1}$ treatment increased the vegetative growth, physiological and yield characteristics as well as leaf and stem anatomical features of soybean plant. Arginine is an essential amino acid and considered as the polyamines precursor, agmatine and proline as well as the molecules of cell signaling glutamine and nitric oxide (Chen et al., 2004, Liu et al., 2006) which produced by decarboxylation of arginine via arginine decarboxylase to form putrescine (Bocherueu, 1999, Evans and Malmberg, 1989). Polyamines and arginine involved in the cell cycle control, cell division, morphogenesis and plant hormone 
mediated process and plant senescence control as well as in responses of plants to different stress factors (Walters, 2000). The application of arginine which is one of the essential amino acids increases and promotes the growth and fresh as well as dry weight, some endogenous growth regulators, chlorophylls a, b and carotenoids in bean plant (Nassar et al., 2003) and wheat (El-Bassiouny et al., 2008). Moreover, many researchers have showed the arginine positive role for alleviating the adverse effects occurring as a result for exposing plant to stress (Hassanein et al., 2008, Khalil et al., 2009). It has been reported that arginine have several roles in higher plants growth responses (Nasibi et al., 2011, Song et al., 1999, Zhang et al., 2011, Zeid, 2009). Exogenous positive effects on growth and development in stress conditions have been found NO (Liu et al., 2011, Neill et al., 2003), PAs (He et al., 2002) and proline (Gioseffi et al., 2012, Patton et al., 2007). Milagrow (Brassinosteroids, BRs) has been found for stimulating cell division and elongation, differentiation of flowering bud, carbohydrate assimilation and activity of ATP, subsequently improving vegetative growth as well as enhancing physiological status then directing plant for earlier harvest and increasing fruit yield and quality features (Gabr et al., 2011, Gomes et al., 2006, Symons et al., 2006). Salazar et al. (2016) reported that Brassinosteroid treatments increased marketable fruit yield of strawberry plant. Milagrow is natural growth promoter, it is extracted from cabbage flowers pollen grain. It promotes growth and flower buds formation, resist dropping of flowers and fruits, increases fruits setting percentage, subsequently increasing of yield and quality. Milagrow has combined effects of auxins, gibberellins, cytokinin, hydrogen cyanamid and ethylene. Its chemical constituents are $0.2 \%$ brassinoliods (BRs), $10 \%$ potassium, 20\% phosphorus and 3\% boron (Attia et al., 2011, Seadh et al., 2012). Attia et al. (2011) mentioned that foliar application with Milagrow significantly recorded the highest values of plant height, number of branches plant ${ }^{-1}$ as well as yielded petal $\mathrm{fed}^{-1}\left(1\right.$ feddan $(\mathrm{fed})=4200 \mathrm{~m}^{2}=0.42$ hectares $=1.038$ acres) of safflower plant. Seadh et al. (2012) reported that the highest values of capitula number plant $^{-1}$, weight of 100 seed of safflower plant. At high temperature, the flower reproductive part is adversely affected. Elongation of stigma tube, pollen poor germination, poor growth of pollen tube and carbohydrate stress are the main reasons to poor fruit set in tomato plant at high temperature. Vollenweider and Gunthardt-Goerg (2005) and Sato et al. (2006) stated that under high temperatures, fruit setting of tomato plant failed due to sugar metabolism disruption and transport during the narrow window of male reproductive development. General environmental changes, especially global warming in Egypt, have adverse effects on crop productivity. So, the main objectives of this study is to investigate if there are positive effects of the growth biostimulant treatments i.e., Arginine, Tryptophan and Milagrow on improving morphological, physiological, anatomical, flowering and yield characteristics as well as their roles in the 
tolerance to the adverse effects of high temperature on tomato plant during summer season.

\section{Materials and methods}

The present study was carried out in the field at The Experimental Farm of Faculty of Agriculture, Moshtohor, Qalubia Governorate, and Agricultural Botany Department, Faculty of Agriculture, AlAzhar University (Assiut Branch), Assiut governorate, Egypt during the two growing successive summer seasons of 2016 and 2017. The experiment was performed as a randomized complete block design with four replicates. In both seasons the normal agricultural practices of growing tomato plant including equal amounts of fertilizer and irrigation water were applied. The applied treatments were used as foliar application at different concentrations as follows: Control (Tap water) 0.0 , Arginine at 25 and $50 \mathrm{mgl}^{-1}$, Tryptophan at 50 and $100 \mathrm{mgl}^{-1}$, Milagrow (Brassinosteroids, BRs) is a class of poly hydroxyl steroids that have been recognized as a class of plant hormones Mitchell et al., (1970) at 50 and $100 \mathrm{mgl}^{-1}$. Plants of each treatment were sprayed three times at 40,55 and 70 DAS throughout the two summer seasons of 2016 and 2017.

\subsection{Sampling and collecting data}

Different vegetative growth characteristics of plant samples were taken at 65 DAS during the experimental period of tomato plant (cv.UC82). Three plants from each treatment were randomly taken for different measurements. The samples of these organs were dried in the oven at $70 \mathrm{C}^{\circ}$ for 48 hours till constant weight. The dried samples of different organs were weighted for dry weight estimation then kept for chemical analysis determinations.

\subsection{Morphological characteristics of vegetative growth}

The following vegetative growth characteristics were estimated i.e., plant length, stem diameter $(\mathrm{cm})$, number of branches plant ${ }^{-1}$, number of leaves plant ${ }^{-1}$, stem fresh weight plant $^{-1}$, leaves fresh weight plant $^{-1}$, stem dray weight plant ${ }^{-1}$, leaves dry weight plant ${ }^{-1}(\mathrm{~g})$ and total leaf area $\left(\mathrm{cm}^{2}\right)$ plant $^{-1}$.

\subsection{Physiological characteristics}

Chemical analysis was carried out at 65 DAS during seasons of 2016 and 2017.

\subsubsection{Determination of photosynthetic pigments in the plant leaves}

Determination of photosynthetic pigments in the plant leaves i.e., chlorophyll A, B, $\mathrm{A}+\mathrm{B}$ and carotenoids $\mathrm{mg} \mathrm{g}^{-1} \quad$ F.Wt. calorimetrically determined in the fresh leaves according to Wettestein (1957).

\subsubsection{Endogenous phytohormones}

Endogenous phytohormones (Promoters) i.e., Gibberellins, Auxins, cytokinins and total promoters as well as the salicylic acid were quantitatively determined in tomato shoot during 2017 season using High Performance Liquid Chromatography (HPLC) according to 
Koshioka et al. (1983) for auxins (IAA), gibberellins, salicylic Acid and abscisic acid (ABA) while cytokinins were determined according to Nicander et al. (1993).

\subsection{Anatomical characteristics}

The effect of foliar application with Arginine at 25 and $50 \mathrm{mgl}^{-1}$, Tryptophan at 50 and $100 \mathrm{mgl}^{-1}$ and Milagrow at 50 and $100 \mathrm{mgl}^{-1}$ treatments comparing with the control (distilled water) on leaflet and stem anatomical characters of tomato (cv. UC82) plants was studied. Specimens of tomato (cv. UC82) terminal leaflets and stems were taken from the $4^{\text {th }}$ apical internode of the main stem and its corresponding leaf of treated plants and those of the control at 65 DAS during season of 2017 only. These specimens were then killed and fixed in F.A.A. (10 $\mathrm{ml}$ formalin, $5 \mathrm{ml}$ glacial acetic acid and $85 \mathrm{ml}$ ethyl alcohol 70\%), washed in 50\% ethyl alcohol, dehydrated in a series of ethyl alcohols 70, 90, 95 and 100\%, infiltrated in xylene embedded in paraffin wax with a melting point $60-63^{\circ} \mathrm{C}$, sectioned 12 microns in thickness for leaflets and stems (Sass, 1951), stained with the double stain method (Fast green and safranin), cleared in xylene and mounted in Canada balsam Johanson (1940). Four sections treatment ${ }^{-1}$ were microscopically inspected to detect histological manifestations of noticeable responses resulted from treatments. Counts and measurements $(\mu)$ were taken using a micrometer eye piece. Averages of readings from 4 slides treatment ${ }^{-1}$ were calculated. Anatomical characteristics of the treated plants compared with the control based on transverse sections of the leaflets and stems were studied.

\subsubsection{Anatomical of leaf}

Anatomical of leaf characters i.e., thickness of upper epidermis tissue, lower epidermis, palisade tissue, spongy tissue, blade, phloem tissue, xylem tissue, No. of xylem rows, thickness of widest $M$. xylem vessel, length of vascular bundle, width of vascular bundle and thickness of leaf midrib.

\subsubsection{Anatomical of stem}

Anatomical of stem characters i.e., thickness of epidermis, collenchyma layers, parenchyma layers, phloem tissue, cambial tissue, xylem tissue, number of xylem rows vascular cylinder ${ }^{-1}$, number of xylem vessels row $^{-1}$, diameter of widest M. xylem vessel, thickness of parenchymamatous pith and stem diameter.

\subsection{The flowering and yield parameters}

\subsubsection{Flowering and yield}

Flowering and yield i.e., earliness of flower anthesis, number of flower plant ${ }^{-1}$, pollen grains fertility percentage, early yield number plant ${ }^{-1}$, early yield plant ${ }^{-1}$, total fruits number plant $^{-1}$, fruit setting percentage, abscission percentage, total yield plant ${ }^{-1}$, fruit fresh weight fruit ${ }^{-1}$ and Fruit dry weight fruit ${ }^{-1}$.

\subsubsection{Fruit chemical compositions}

Fruit chemical compositions i.e., nitrogen, phosphorus, potassium, crude protein, 
total carbohydrates, total soluble solid, total acidity, vitamin $\mathrm{C} \mathrm{mg} 100^{-1} \mathrm{~cm} 3$ juice were determined according to A.O.A.C. (2005).

\subsection{Statistical analysis}

Data of vegetative growth, yield characteristics and chemical constituents were statistically analyzed and the means were compared using the Least Significant Difference test (L.S.D) at 5\% level according to Snedecor and Cochran (1980).

\section{Results and Discussion}

\subsection{Morphological characteristics of vegetative growth}

Data in Table (1) show that, all the levels of treatments significantly increased the vegetative growth parameters i.e., plant length, stem diameter, number of branches plant ${ }^{-1}$, number of leaves plant ${ }^{-1}$, stem fresh weight plant $^{-1}$, leaves fresh weight plant $^{-1}$, stem dray weight plant $^{-1}$, leaves dry weight plant $^{-1}$ and total leaf areaplant $^{-1}$. From these results can conclude that, the best treatment was Milagrow at $50 \mathrm{mgl}^{-1}$ flowed by Arginine at $50 \mathrm{mgl}^{-1}$ comparing with the control during both seasons. On the other side, the treatment with tryptophan, recorded low values compared with Milagrow and Arginine treatments, especially at 50 $\mathrm{mgl}^{-1}$. In this respect, the increasing of formed branches on growing plant could be reversed upon many other characteristics such leaves number, leaf area, leaves dry weight as well as increasing the photosynthetic efficiency, flowering and finally the yielded fruits. Foliar application with Milagrow at 50 ppm twice after 30 and 70 DAS significantly recorded the highest values of plant height, number of branches plant $^{-1}$ of safflower (Attia et al., 2011). Milagrow (Brassinosteroids, BRs) has been found to stimulate cell division and elongation, flowering bud differentiation, carbohydrate assimilation and ATP activity, subsequently vegetative growth improving (Gabr et al., 2011, Gomes et al., 2006, Symons et al., 2006). At the same time Arginine treatment significantly increased wheat fresh and dry weight (El-Bassiouny et al., 2008). Moreover, it was reported that arginine has important roles in different environmental stresses, such salinization by scavenging free radical species (Zhang et al., 2011). Arginine application significantly promote growth through increasing fresh as well as dry weight of bean plant (Nassar et al., 2003) and wheat plant (El- Bassiouny et al., 2008).

\subsection{Physiological characteristics}

\subsubsection{Photosynthetic pigments content}

The data in Table (2) clearly indicate that, all the applied treatments significantly increased the photosynthetic pigments content in the plant leaves i.e., chlorophyll A, B, A+B and carotenoids $\mathrm{mg} \mathrm{g}^{-1}$ F.Wt. From these results we can conclude that, the beast treatment was Milagrow at $50 \mathrm{mgl}^{-1}$ comparing with the control and other treatments during both seasons. Moreover, there're negative correlation between chlorophyll content 
A, B and A+B with carotenoids concentration in the leaves with treatments. In general, data in Table (2) not only being a direct results for that vigorous growth obtained in Table (1) but also could be considered an indicator for expectable high yield of fruits. These results are of great interest, because they are lightly considered direct reason for the more dry matter production and distribution in shoots of tomato plants as affected by different applied treatments. The brassinosteroid application in wheat plant stimulated photosynthetic activity expressed by acceleration in fixing of $\mathrm{CO} 2$, increasing biosynthesis of protein (Braun and Wild, 1984) and in mustard plant, increased rates of photosynthesis which related to growth and seed production directly (Hayat et al., 2000). It is also evident that brassinosteroids regulate the metabolism of growth through the signals of auxins for promoting cell division, development of root hairs, xylem differentiation, development of pollen, seed setting as well as yield output (Hayat et al., 2003). Moreover, Clouse (1996) showed that BRs have been shown for enhancing differentiation of tracheae, stimulate hyperpolarization of membranes as well as activity of ATPase, promoting ethylene bio synthesis, control orientation of microtubule and alter mechanical of cell walls properties. The arginine treatment significantly increased some growth regulators, chlorophylls and carotenoids contents in bean plant (Nassar et al., 2003) and wheat plant (El-Bassiouny et al., 2008). Tryptophan acts as an osmolyte, regulator of ion transport, modulating of stomata opening and detoxifing of stress harmful effects (Orabi et al., 2014, Rai, 2002). Pathway of tryptophan is playing a defensive role in plants (Hussein et al., 2014).

Table (1): Morphological characters in tomato plants as affected by some biostimulants at 65 DAS during 2016 and 2017 seasons.

\begin{tabular}{|c|c|c|c|c|c|c|c|c|c|}
\hline Treatments & $\begin{array}{l}\text { Plant } \\
\text { length } \\
(\mathrm{cm}) \\
\end{array}$ & $\begin{array}{c}\text { Stem } \\
\text { diameter } \\
(\mathrm{cm}) \\
\end{array}$ & $\begin{array}{l}\text { No. of } \\
\text { branches } \\
\text { plant }^{-1}\end{array}$ & $\begin{array}{l}\text { No. of } \\
\text { leaves } \\
\text { plant }^{-1} \\
\end{array}$ & $\begin{array}{l}\text { Stems } \\
\text { F.Wt.g } \\
\text { plant }^{-1} \\
\end{array}$ & $\begin{array}{l}\text { Leaves } \\
\text { F.Wt.g } \\
\text { plant }^{-1} \\
\end{array}$ & $\begin{array}{l}\text { Stems } \\
\text { D.Wt.g } \\
\text { plant }^{-1} \\
\end{array}$ & $\begin{array}{l}\text { Leaves } \\
\text { D.Wt.g } \\
\text { plant }^{-1} \\
\end{array}$ & $\begin{array}{c}\text { Total leaf } \\
\text { area plant } \\
\left(\mathrm{cm}^{2}\right) \\
\end{array}$ \\
\hline \multicolumn{10}{|c|}{ Season 2016} \\
\hline Control & 54.28 & 1.15 & 5.52 & 27.61 & 41.43 & 83.87 & 5.76 & 16.31 & 2407.08 \\
\hline Arginine at $25 \mathrm{mgl}^{-1}$ & 63.69 & 1.32 & 6.87 & 36.50 & 50.08 & 97.69 & 6.09 & 17.50 & 2671.52 \\
\hline Arginine at $50 \mathrm{mgl}^{-1}$ & 71.49 & 1.70 & 7.53 & 43.43 & 74.12 & 161.60 & 9.45 & 31.82 & 3622.86 \\
\hline Tryptophan at $50 \mathrm{mgl}^{-1}$ & 59.12 & 1.30 & 6.14 & 34. 76 & 48.73 & 94.13 & 8.90 & 21.20 & 2623.01 \\
\hline Tryptophan at $100 \mathrm{mgl}^{-1}$ & 68.10 & 1.36 & 7.11 & 38.55 & 66.37 & 128.42 & 7.86 & 23.60 & 3230.35 \\
\hline Milagrow at $50 \mathrm{mgl}^{-1}$ & 74.26 & 1.71 & 8.16 & 45.66 & 83.13 & 165.66 & 11.45 & 32.53 & 4416.29 \\
\hline Milagrow at $100 \mathrm{mgl}^{-1}$ & 69.07 & 1.37 & 7.09 & 36.70 & 59.26 & 112.08 & 7.58 & 22.37 & 3112.14 \\
\hline L.S.D. 0.05 & 4.15 & 0.04 & 0.82 & 4.17 & 6.22 & 9.16 & 1.19 & 2.63 & 187.26 \\
\hline \multicolumn{10}{|c|}{ Season 2017} \\
\hline Control & 60.28 & 1.30 & 5.70 & 33.17 & 40.22 & 87.17 & 6.68 & 16.77 & 2592.66 \\
\hline Arginine at $25 \mathrm{mgl}^{-1}$ & 62.38 & 1.64 & 6.33 & 33.91 & 55.07 & 108.40 & 8.41 & 18.17 & 3176.38 \\
\hline Arginine at $50 \mathrm{mgl}^{-1}$ & 68.03 & 1.57 & 7.12 & 41.53 & 66.69 & 125.33 & 9.06 & 25.80 & 3433.31 \\
\hline Tryptophan at $50 \mathrm{mgl}^{-1}$ & 58.92 & 1.35 & 6.31 & 34. 08 & 43.17 & 91.27 & 7.23 & 17.70 & 2672.22 \\
\hline Tryptophan at $100 \mathrm{mgl}^{-1}$ & 67.49 & 1.55 & 6.47 & 36.60 & 58.30 & 117.57 & 8.46 & 22.65 & 3327.49 \\
\hline Milagrow at $50 \mathrm{mgl}^{-1}$ & 70.60 & 1.62 & 7.23 & 42.24 & 78.68 & 143.82 & 10.02 & 27.22 & 4055.46 \\
\hline Milagrow at $100 \mathrm{mgl}^{-1}$ & 63.71 & 1.44 & 6.26 & 35.09 & 57.88 & 98.61 & 8.34 & 17.93 & 2714.00 \\
\hline L.S.D. 0.05 & 3.27 & 0.12 & 0.74 & 3.52 & 4.57 & 6.09 & 0.98 & 1.18 & 205.43 \\
\hline
\end{tabular}


3.2.2 Endogenous phytohormones and salicylic acid contents of tomato shoot

As shown in Table (3) it could be noticed that different applied biostimulants significantly increased the endogenous phytohormones content (Promoters) i.e., gibberellins, auxins, cytokinins and total promoters as well as the salicylic acid in the plant shoot. From these results we can conclude that, the beast treatment was Milagrow at $50 \mathrm{mgl}^{-1}$ which increased the promoters and salicylic acid contents in the shoot, but low values was recorded with the Arginine at 25 $\mathrm{mgl}^{-1}$, in addition to, the highest values with total promoters $(637,27)$ and cytokines (468.25) $\mu \mathrm{g} \mathrm{g}^{-1}$ F.Wt. were recorded with the same dose of Milagrow during the season of study. On the contrast, the lowest value was recorded for the inhibitor (ABA) $0.55 \mu \mathrm{g}$ $\mathrm{g}^{-1}$ F.Wt. Moreover, there're, positive correlation between gibberellins and auxins with tryptophan treatment especially at $100 \mathrm{mgl}^{-1}$. Increment of endogenous phytohormones in tomato plant obtained in the present study could be interpret both of the obtained modifications in different studied histological features as will be mentioned later Tables (4 and 5) and the growth improvement Table (1) as well as enhancement of bioconstituents Tables ( 2 and 7) and yield Table (6). For example, increasing cytokinins could be in favor of increasing the formed branches number and that could increase transverse growth on the account of longitudinal one as well as increasing of sink organs (i.e., fruits) ability to accumulate and storage more assimilates. Milagrow is natural growth promoter extracted from cabbage flowers pollen grains. It is growth promoter, it has combined effects of auxin, gibberellin, cytokinin, ethylene as well as hydrogen cyanamid. Its chemical compositions are $0.2 \%$ brassinoliods, $20 \%$ phosphorus, $10 \%$ potassium and 3\% boron (Attia et al., 2011, Seadh et al., 2012). Polyamines and their precursor arginine have been implicated as vital modulators in higher plants growth, physiological as well as developmental processes (Glastone and Kaur-Sawhny, 1990). Polyamines are involved in the cell cycle control, cell division and plant hormones mediated process and the plant senescence control as well as in plant response to different stress factors (Walters, 2000).

\subsection{Anatomical characteristics}

\subsubsection{Anatomical characteristics of leaf}

Data in Table (4) and Figure (1) indicate that, all biostimulant treatments significantly increased the anatomical of leaf characters i.e., thickness of upper epidermis, lower epidermis tissue, palisade tissue, spongy tissue, blade, phloem tissue, xylem tissue, number of xylem rows, thickness of widest $\mathrm{M}$. xylem vessel, length of vascular bundle, width of vascular bundle and thickness of leaf midrib. From these results can conclude that, the beast treatment was 
milagrow at $50 \mathrm{mgl}^{-1}$ for thickness of lower epidermis tissue $(16 \mu)$, palisade tissue $(189 \mu)$, spongy tissue $(230 \mu)$, blade $(477 \mu)$, phloem tissue $(241 \mu)$ and xylem tissue $(592 \mu)$ respectively, followed by tryptophan treatment 50 $\mathrm{mgl}^{-1}$ which improved the xylem tissue $(608 \mu)$, number of xylem rows (23), thickness of widest M. xylem vessel

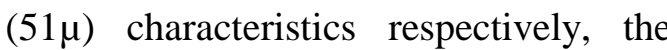
same results were obtained from tryptophan treatment with length of vascular bundle $(727 \mu)$, width of vascular bundle $(488 \mu)$ and thickness of leaf midrib (1793 $\mu)$ especially at 100 $\mathrm{mgl}^{-1}$, On the other side, the control treatment recorded the lowest value for thickness of leaf midrib $(1481 \mu)$.

Table (2): Photosynthetic pigments content of tomato leaves as affected by some biostimulants at 65 DAS during 2016 and 2017 seasons.

\begin{tabular}{|c|c|c|c|c|}
\hline \multirow[t]{2}{*}{ Characteristics } & \multicolumn{3}{|c|}{ Chlorophyll mg g ${ }^{-1}$ F.Wt. } & \multirow{2}{*}{$\begin{array}{l}\text { Carotenoids } \\
\mathrm{mg} \mathrm{g}^{-1} \text { F.Wt. }\end{array}$} \\
\hline & (A) & (B) & $(\mathrm{A}+\mathrm{B})$ & \\
\hline \multicolumn{5}{|c|}{ Season 2016} \\
\hline Control & 0.82 & 0.51 & 1.33 & 0.67 \\
\hline Arginine at $25 \mathrm{mgl}^{-1}$ & 0.94 & 0.59 & 1.53 & 0.64 \\
\hline Arginine at $50 \mathrm{mgl}^{-1}$ & 1.15 & 0.56 & 1.71 & 0.76 \\
\hline Tryptophan at $50 \mathrm{mgl}^{-1}$ & 0.91 & 0.54 & 1.45 & 0.87 \\
\hline Tryptophan at $100 \mathrm{mgl}^{-1}$ & 1.09 & 0.49 & 1.58 & 0.74 \\
\hline Milagrow at $50 \mathrm{mgl}^{-1}$ & 1.21 & 0.61 & 1.82 & 0.81 \\
\hline Milagrow at $100 \mathrm{mgl}^{-1}$ & 0.95 & 0.65 & 1.60 & 0.74 \\
\hline L.S.D. 0.05 & 0.11 & 0.08 & 0.21 & 0.06 \\
\hline \multicolumn{5}{|c|}{ Season 2017} \\
\hline Control & 1.03 & 0.47 & 1.50 & 0.70 \\
\hline Arginine at $25 \mathrm{mgl}^{-1}$ & 0.83 & 0.70 & 1.53 & 0.68 \\
\hline Arginine at $50 \mathrm{mgl}^{-1}$ & 1.10 & 0.63 & 1.73 & 0.83 \\
\hline Tryptophan at $50 \mathrm{mgl}^{-1}$ & 0.97 & 0.54 & 1.51 & 0.83 \\
\hline Tryptophan at $100 \mathrm{mgl}^{-1}$ & 1.12 & 0.58 & 1.70 & 0.81 \\
\hline Milagrow at $50 \mathrm{mgl}^{-1}$ & 1.22 & 0.59 & 1.81 & 0.65 \\
\hline Milagrow at $100 \mathrm{mgl}^{-1}$ & 1.08 & 0.72 & 1.80 & 0.76 \\
\hline L.S.D. 0.05 & 0.04 & 0.10 & 0.15 & 0.03 \\
\hline
\end{tabular}

Table (3): Endogenous phytohormones and salicylic acid content in tomato shoot as affected by some biostimulants at 65 DAS during 2017 season.

\begin{tabular}{|c|c|c|c|c|c|c|}
\hline \multirow[b]{2}{*}{ Treatments } & \multicolumn{4}{|c|}{ Promoters $\mu \mathrm{g} \mathrm{g}^{-1}$ F.Wt. } & \multirow{2}{*}{$\begin{array}{c}\text { Inhibitors } \\
\text { (Abscisic acid) } \\
\mu \mathrm{g} \mathrm{g}^{-1} \text { F.Wt. }\end{array}$} & \multirow{2}{*}{$\begin{array}{l}\text { Salicylic acid } \\
\mu \mathrm{g} \mathrm{g}^{-1} \text { F.Wt. }\end{array}$} \\
\hline & Gibberellins & Auxins & Cytokinins & $\begin{array}{c}\text { Total } \\
\text { Promoters }\end{array}$ & & \\
\hline Control & 123.67 & 12.33 & 340.50 & 476.50 & 0.96 & 2.18 \\
\hline Arginine at $25 \mathrm{mgl}^{-1}$ & 126.73 & 13.10 & 381.70 & 521.53 & 0.38 & 1.38 \\
\hline Arginine at $50 \mathrm{mgl}^{-1}$ & 159.11 & 15.14 & 454.28 & 636.65 & 0.62 & 2.91 \\
\hline Tryptophan at $50 \mathrm{mgl}^{-1}$ & 103.29 & 10.98 & 397.23 & 511.50 & 0.67 & 2.11 \\
\hline Tryptophan at $100 \mathrm{mgl}^{-1}$ & 167.23 & 17.33 & 43314 & 609.58 & 0.57 & 1.53 \\
\hline Milagrow at $50 \mathrm{mgl}^{-1}$ & 154.40 & 14.62 & 468.25 & 637.27 & 0.55 & 3.25 \\
\hline Milagrow at $100 \mathrm{mgl}^{-1}$ & 118.03 & 11.60 & 417.19 & 546.82 & 0.84 & 2.70 \\
\hline
\end{tabular}


Brassinosteroids are steroids which occur in several plant species with biological activities, they are a new plant growth hormones group (Yokota and Takahashi, 1985). Brassinosteroids affect many biological processes, such as stem elongation, leaf bending as well as xylem formation (Yokota, 1997). These activities of development are associated with activity of ATPase (Cerana et al., 1983), 1-aminocyclopropane-1-carboxylic acid synthase (Arteca et al., 1983), alteration of micro tubule orientation (Mayumi and Shibaoka, 1995) and cell walls modification (Zurek et al., 1994). Clouse and Zurek (1991) indicated that exogenously applied brassinolide, the most active brassinosteroid, promoted differentiation of tracheae and cell division. Helal and Gomaa (2007) reported that stigmasterol induced significant a promotive effects on stem and leaf anatomical structure of lupine plant. El-Badawy and Abd El-Aal (2013) indicated that tryptophan foliar application improved the most of mango plant leaf anatomical features. Abd El-Aal and Eid (2018) found that foliar application with amino acids at $4 \mathrm{mll}^{-1}$ treatment enhanced leaf and stem anatomical features of soybean plant.

\subsubsection{Anatomical characteristics of stem}

Data in Table (5) and Figure (2) show that all the levels of treatments significantly increased the anatomical of stem characteristics i.e., thickness of epidermis tissue, collenchyma layers, parenchyma layers, phloem tissue, cambial tissue, xylem tissue, number of xylem rows vascular cylinder ${ }^{-1}$, number of xylem vessels row $^{-1}$, diameter of widest $M$. xylem vessel, thickness of parenchymamatous pith and stem diameter. From these results can conclude that, the beast treatment was milagrow at $50 \mathrm{mgl}^{-1}$ which recorded the highest values for thickness of epidermis tissue $(17 \mu)$, collenchyma layers $(251 \mu)$, phloem tissue $(266 \mu)$, cambial tissue $(109 \mu)$, xylem tissue $(841 \mu)$ and diameter of widest M. xylem vessel $(86 \mu)$ respectively, but the concentration at 100 $\mathrm{mgl}^{-1}$ recorded the highest values for thickness of parenchymamatous pith $(2809 \mu)$ and stem diameter $(5940 \mu)$ comparing with the control. On the other side, the treatment with arginine, recorded low values, especially at $25 \mathrm{mgl}^{-1}$ compared with Milagrow and tryptophan treatments in certain histological features since, thickness of cambial tissue was $(57 \mu)$, xylem tissue $(560 \mu)$, number of xylem rows vascular cylinder ${ }^{-1}$ (56), number of xylem vessels row $^{-1}$ (15), thickness of parenchymamatous pith $(1962 \mu)$ and stem diameter $(4551 \mu)$ flowed by the treatment with tryptophan, especially at $50 \mathrm{mgl}^{-1}$ for thickness of collenchyma layers $(163 \mu)$, parenchyma layers $(248 \mu)$, phloem tissue $(181 \mu)$ and number of xylem vessels row $^{-1}$ (15) respectively, comparing with the other biostimulant treatments. 


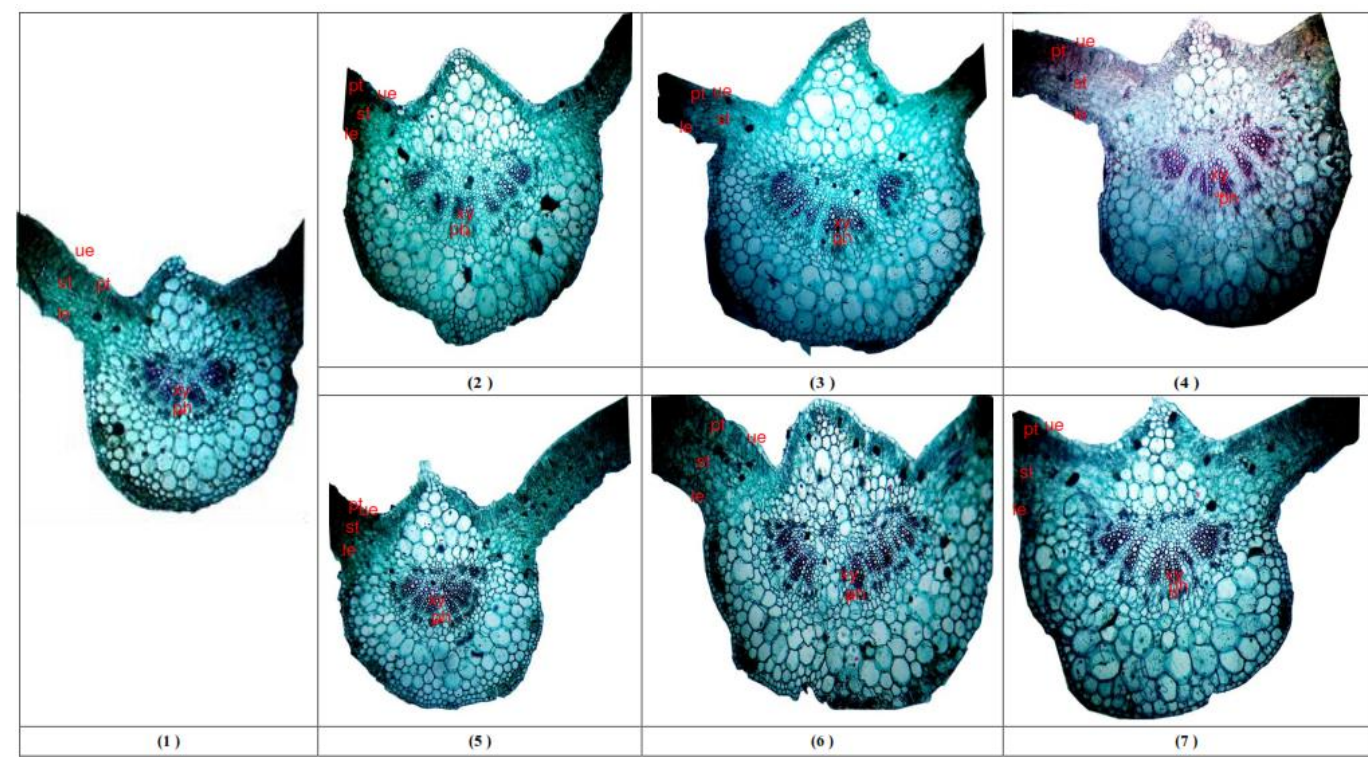

Figure (1): Transverse sections $(X=40)$ through $4^{\text {th }}$ apical leaf of Lycopersicon esculentum Mill plant at 65 DAS as affected by different applied treatments. Where: (1): Control, (2): Arginine at $25 \mathrm{mgl}^{-1}$, (3): Arginine at $50 \mathrm{mgl}^{-1},(4)$ : Tryptophan at $50 \mathrm{mgl}^{-1},(5)$ : Tryptophan at $100 \mathrm{mgl}^{-1},(6)$ : Milagrow at $50 \mathrm{mgl}^{-1}$, (7): Milagrow at $100 \mathrm{mgl}^{-1}$, ue $=$ upper epidermis, le $=$ lower epidermis, $\mathrm{pt}=$ palisade tissue, $\mathrm{st}=\mathrm{spongy}$ tissue, $\mathrm{ph}=$ phloem tissue, $\mathrm{xy}=$ xylem tissue.

Table (4): Anatomical structure of tomato leaf as affected by some biostimulants at 65 DAS during 2017 season.

\begin{tabular}{|c|c|c|c|c|c|c|c|}
\hline $\begin{array}{ll}\text { Histological } & \text { Treatments } \\
\text { Characteristics (micron) }\end{array}$ & Control & $\begin{array}{l}\text { Arginine } \\
\text { at } 25 \mathrm{mgl}^{-1}\end{array}$ & $\begin{array}{l}\text { Arginine } \\
\text { at } 50 \mathrm{mgl}^{-1}\end{array}$ & $\begin{array}{l}\text { Tryptophan } \\
\text { at } 50 \mathrm{mgl}^{-1}\end{array}$ & $\begin{array}{l}\text { Tryptophan } \\
\text { at } 100 \mathrm{mgl}^{-1}\end{array}$ & $\begin{array}{l}\text { Milagrow } \\
\text { at } 50 \mathrm{mgl}^{-1}\end{array}$ & $\begin{array}{c}\text { Milagrow at } \\
100 \mathrm{mgl}^{-1}\end{array}$ \\
\hline Thickness of upper epidermis tissue & 21 & 24 & 23 & 19 & 25 & 18 & 22 \\
\hline Thickness of lower epidermis tissue & 14 & 13 & 15 & 13 & 16 & 16 & 12 \\
\hline Thickness of palisade tissue & 115 & 112 & 152 & 103 & 174 & 189 & 170 \\
\hline Thickness of spongy tissue & 162 & 219 & 235 & 187 & 216 & 230 & 181 \\
\hline Thickness of xylem tissue & 473 & 521 & 610 & 608 & 587 & 592 & 513 \\
\hline No. of xylem rows & 18 & 19 & 21 & 23 & 20 & 21 & 22 \\
\hline Widest of M. xylem vessel & 34 & 42 & 50 & 51 & 44 & 43 & 46 \\
\hline Length of midrib vascular bundle & 662 & 690 & 738 & 721 & 727 & 643 & 709 \\
\hline
\end{tabular}

Finally, the leaf and stem anatomical characteristics indicate that Milagrow was the beast treatment for enhancement the anatomical structure of tomato leaf and stem i.e., number of rows in the leaf and stem especially at $50 \mathrm{mgl}^{-1}$ as well as increasing the thickness of leaf lamina and midrib especially at $100 \mathrm{mgl}^{-1}$, subsequently increasing the mineral elements transport and photosynthetic rate. Moreover, the tolerance to adverse conditions especially at high temperature 
for tomato genotypes during summer season. In general, the stimulatory effects of applied biostimulants on the anatomy features of treated plants could be due to the effect upon cambium activity. Increment of cambium activity could attributed to the increasing of endogenous phytohormones level especially auxins and cytokinins. The above mentioned results especially the conductive tissues increment i.e., xylem and phloem tissues are of great importance because they could be involved in the interpretation about why vigorous growth and high yield fruits were existed with different applied treatments especially with Milagrow at $50 \mathrm{mgl}^{-1}$. Iwasaki and Shibaoka (1991) mentioned that brassinosteroids producing differentiation of parenchymatous cells into tracheae element. Brassinosteroid is known for acting synergistically with auxin for stimulating cell elongation (Katsumi, 1985, Sasse, 1990). Brassinosteroids enhance sensitivity of tissues to auxin (Mandava, 1988). It is now well known that Brassinosteroids are plant growth regulators which regulate positively plant growth under normal as well as stress conditions (Bajguz and Hayat, 2009, Divi and Krishna, 2009). They regulate the metabolism of growth through the auxin signals for promoting cell division, development of root hairs, differentiation of xylem (Hayat et al., 2003). Paschalidis and Roubelakis-Angelakis (2005) indicated that polyamines and their precursor arginine as well as their enzymes biosynthesis involved in stimulation of cell division, expansion and differentiation as well as vascular development in tobacco. Akladious and
Abbas (2013) and El-Desouky et al. (2011) found that using of amino acids mixture led to an increasing in stem diameter of tomato plant as a result for increasing in the thickness of epidermis and cortex as well as increasing the xylem thickness, especially the vessels number compared to non-treated plant.

\subsection{The flowering and yield parameters}

\subsubsection{Flowering and yield}

Data in Table (6) indicate that all the biostimulant treatments significantly increased the flowering and yield parameters i.e., earliness of flower anthesis, number of flowers plant ${ }^{-1}$, pollen grains fertility percentage, early yield number plant ${ }^{-1}$, early yield (g) plant ${ }^{-1}$, total fruits number plant ${ }^{-1}$, fruit setting percentage, abscission percentage, total yield $(\mathrm{kg})$ plant $^{-1}$, fruit fresh weight $(\mathrm{g})$ fruit $^{-1}$ and fruit dry weight $(\mathrm{g})$ fruit $^{-1}$. From these results can conclude that, the beast treatment was milagrow at $50 \mathrm{mgl}^{-1}$ which recorded the highest values for early yield $(\mathrm{g})$ plant $^{-1}(731.62)$, total fruits number plant ${ }^{-1}(29.74)$, fruit setting percentage (37.19), total yield $(\mathrm{kg})$ plant $^{-1}$ (1.94), fruit fresh weight fruit ${ }^{-1}(67.38 \mathrm{~g})$ and fruit dry weight fruit ${ }^{-1}(3.14 \mathrm{~g})$ flowed by the tryptophan treatment at $100 \mathrm{mgl}^{-1}$ which recorded high values for earliness of flower anthesis (13.70), pollen grains fertility percentage (17.73), early yield number of plant (11.07) in the first season. But in the second seasons all the biostimulant treatments recoded high values comparing with the control. On the other side, the treatment with tryptophan 
at $50 \mathrm{mgl}^{-1}$ recorded low values for early yield number of plant (9.05), early yield (g) plant ${ }^{-1}(605.85)$, total fruits number plant $^{-1}$ (23.45), fruit setting percentage (32.03), total yield $(\mathrm{kg})$ plant $^{-1}(1.58)$, fruit fresh weight fruit ${ }^{-1}(65.23 \mathrm{~g})$ and Fruit dry weight fruit ${ }^{-1}(2.71 \mathrm{~g})$ comparing with the other biostimulant treatments. In the same trained for the arginine treatment at $25 \mathrm{mgl}^{-1}$ especially in the second season during the same field conditions. Herein, it was clear that the stimulative effects of such treatments on tomato fruits yield was mainly due to their promotional effects on fruits setting and fruits number plant ${ }^{-1}$ rather than fruits weight. This also could be attributed to the pronounced enhancement effects of the same treatments on growth behavior, $\mathrm{N}, \mathrm{P}$ and $\mathrm{K}$ contents, metabolic activity i.e., chlorophyll and carbohydrate contents and the antioxidant bio constituents i.e., carotenoids content. All of them were positively correlated with fruit yield. Milagrow is natural growth promoter. It is growth promoting, increases yield and quality, increases fruit setting percentage, promotes flowering buds formation and resist flowers and fruits dropping.

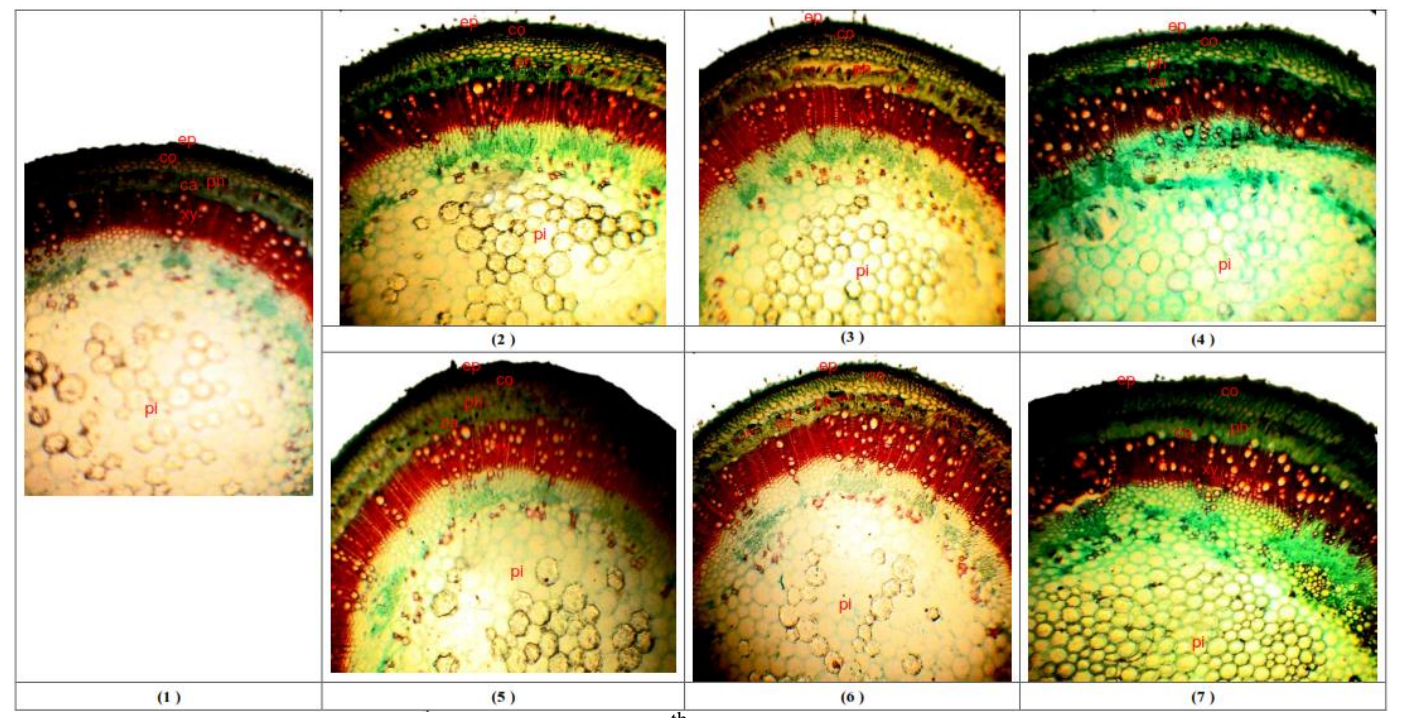

Figure (2): Transverse sections ( $\mathrm{X}=40)$ through $4^{\text {th }}$ internode of Lycopersicon esculentum Mill plants at 65 DAS as affected by different applied treatments. Where: (1): Control, (2): Arginine at $25 \mathrm{mgl}^{-1}$, (3): Arginine at $50 \mathrm{mgl}^{-1}$, (4): Tryptophan at $50 \mathrm{mgl}^{-1}$, (5): Tryptophan at $100 \mathrm{mgl}^{-1}$, (6): Milagrow at $50 \mathrm{mgl}^{-1}$, (7): Milagrow at $100 \mathrm{mgl}^{-1}, \mathrm{ep}=$ epidermis, $\mathrm{co}=$ cortex, $\mathrm{ph}=\mathrm{phloem}$ tissue, $\mathrm{xy}=\mathrm{xylem}$ tissue, $\mathrm{ca}=\mathrm{cambium}$ $\mathrm{pi}=$ pith.

Milagrow found to stimulate flowering buds differentiation, assimilation of carbohydrate and ATP activity, subsequently improving vegetative growth and directed plants to earlier harvest as well as increasing fruit yield and quality characteristics (Gabr et al., 2011, Gomes et al., 2006, Symons et al., 2006). Attia et al., (2011) and Seadh et al. (2012) recorded that the highest values of safflower capitula number plant ${ }^{-1}$, weight of 100 seed as well as seed yield fed $^{-1}$ 
were obtained with milagrow application at rate of $50 \mathrm{ppm}$. Salazar et al., (2016) stated that brassinosteroid treatments increased marketable fruit yield of strawberry plant. The yield increasing in fruit plants may be due to improving the photosynthetic assimilation efficiency of carbon of treated plants. The application of brassinosteroid stimulated activity of photosynthesis expressed with acceleration in $\mathrm{CO}_{2}$ fixation, increasing protein biosynthesis in wheat and mustard plants and that were related to growth and seed production directly.

Table (5): Anatomical structure of tomato stem as affected by some biostimulants at 65 DAS during 2017 season.

\begin{tabular}{|c|c|c|c|c|c|c|c|}
\hline $\begin{array}{l}\text { Histological Treatments } \\
\text { Characteristics (micron) }\end{array}$ & Control & $\begin{array}{l}\text { Arginine at } \\
25 \mathrm{mgl}^{-1}\end{array}$ & $\begin{array}{c}\text { Arginine at } \\
50 \mathrm{mgl}^{-1}\end{array}$ & $\begin{array}{l}\text { Tryptophan } \\
\text { at } 50 \mathrm{mgl}^{-1}\end{array}$ & $\begin{array}{l}\text { Tryptophan } \\
\text { at } 100 \mathrm{mgl}^{-1}\end{array}$ & $\begin{array}{l}\text { Milagrow } \\
\text { at } 50 \mathrm{mgl}^{-1}\end{array}$ & $\begin{array}{c}\text { Milagrow at } \\
100 \mathrm{mgl}^{-1}\end{array}$ \\
\hline Thickness of epidermis tissue & 13 & 15 & 16 & 14 & 13 & 17 & 12 \\
\hline Thickness of collenchyma layers & 185 & 166 & 217 & 163 & 189 & 251 & 234 \\
\hline Thickness of parenchyma layers & 292 & 272 & 280 & 248 & 251 & 274 & 313 \\
\hline Thickness of phloem tissue & 179 & 215 & 277 & 181 & 265 & 266 & 256 \\
\hline Thickness of cambial tissue & 54 & 57 & 73 & 83 & 79 & 109 & 68 \\
\hline Thickness of xylem tissue & 472 & 560 & 794 & 665 & 778 & 841 & 656 \\
\hline No. of xylem /rows vascular cylinder & 74 & 56 & 82 & 77 & 86 & 78 & 65 \\
\hline No. of xylem vessels /row & 12 & 15 & 18 & 15 & 21 & 19 & 17 \\
\hline Widest of M. xylem vessel & 48 & 61 & 72 & 59 & 51 & 86 & 55 \\
\hline Thickness of parenchymatous pith & 2107 & 1962 & 2311 & 2123 & 2478 & 2209 & 2809 \\
\hline Stem diameter & 4417 & 4551 & 5594 & 4843 & 5642 & 5725 & 5940 \\
\hline
\end{tabular}

Table (6): Flowering and yield parameters in tomato plants as affected by some biostimulants during 2016 and 2017 seasons.

\begin{tabular}{|c|c|c|c|c|c|c|c|c|c|c|c|}
\hline Treatments & $\begin{array}{c}\text { Earliness } \\
\text { of flower } \\
\text { anthesis } \\
\text { (days) }\end{array}$ & $\begin{array}{l}\text { No. of } \\
\text { flowers } \\
\text { plant }^{-1}\end{array}$ & $\begin{array}{l}\text { pollen } \\
\text { grains } \\
\text { fertility } \\
\%\end{array}$ & $\begin{array}{l}\text { Early } \\
\text { yield } \\
\text { No. } \\
\text { plant }^{-1}\end{array}$ & $\begin{array}{c}\text { Early } \\
\text { yield g } \\
\text { plant }^{-1}\end{array}$ & $\begin{array}{l}\text { Total } \\
\text { fruits } \\
\text { No. } \\
\text { plant }^{-1}\end{array}$ & $\begin{array}{l}\text { Fruit } \\
\text { setting } \\
(\%)\end{array}$ & $\begin{array}{c}\text { Abscissi } \\
\text { on (\%) }\end{array}$ & $\begin{array}{c}\text { Total } \\
\text { yield } \mathrm{kg} \\
\text { plant }^{-1}\end{array}$ & $\begin{array}{l}\text { Fruit } \\
\text { F.Wt.g } \\
\text { fruit }^{-1}\end{array}$ & $\begin{array}{l}\text { Fruit } \\
\text { D.Wt.g } \\
\text { fruit }^{-1}\end{array}$ \\
\hline \multicolumn{12}{|c|}{ Season 2016} \\
\hline$\overline{\text { Control }}$ & 0.00 & 63.59 & 10.07 & 5.39 & 334.60 & 21.13 & 33.23 & 66.77 & 1.29 & 61.05 & 2.53 \\
\hline Arginine at $25 \mathrm{mgl}^{-1}$ & 11.22 & 76.06 & 13.85 & 9.66 & 642.15 & 26.59 & 34.96 & & 1.76 & 66.19 & 3.01 \\
\hline Arginine at $50 \mathrm{mgl}^{-1}$ & 10.61 & 81.75 & 11.78 & 10.30 & 727.23 & 28.27 & 34.58 & 65.42 & 1.85 & 65.44 & 2.95 \\
\hline Tryptophan at $50 \mathrm{mgl}^{-1}$ & 8.76 & 73.21 & 12.60 & 9.05 & 605.85 & 23.45 & 32.03 & 67.97 & 1.58 & 65.23 & 2.71 \\
\hline Tryptophan at $100 \mathrm{mgl}^{-1}$ & 13.70 & 74.23 & 17.73 & 11.07 & 668.13 & 27.41 & 36.93 & 63.07 & 1.80 & 65.67 & 3.07 \\
\hline Milagrow at $50 \mathrm{mgl}^{-1}$ & 11.19 & 79.96 & 14.39 & 10.33 & 731.62 & 29.74 & 37.19 & 62.81 & 1.94 & 67.38 & 3.14 \\
\hline Milagrow at $100 \mathrm{mgl}^{-1}$ & 7.42 & 68.42 & 15.71 & 10.72 & 713.33 & 26.75 & 39.10 & 60.90 & 1.77 & 66.17 & 2.63 \\
\hline L.S.D. 0.05 & 6.15 & 4.31 & 1.06 & 2.81 & 91.24 & 2.67 & 1.22 & 1.14 & 0.28 & 2.13 & 0.17 \\
\hline \multicolumn{12}{|c|}{ Season 2017} \\
\hline$\overline{\text { Control }}$ & 0.00 & 69.74 & 12.32 & 7.34 & 378.18 & 23.09 & 33.11 & 66 & 1.17 & 50.67 & 2.12 \\
\hline Arginine at $25 \mathrm{mgl}^{-1}$ & & 71.46 & 13.63 & 11.59 & 617.04 & 25.38 & 35.52 & 64 & 1.37 & 53.98 & 2.66 \\
\hline Arginine at $50 \mathrm{mgl}^{-1}$ & & 73.25 & 15.31 & 11.84 & 701.16 & 31.17 & 42.55 & 57.45 & 1.87 & 59.99 & 2.88 \\
\hline Tryptophan at $50 \mathrm{mgl}^{-1}$ & 13.52 & 75.92 & 16.75 & 11.09 & 607.31 & 27.33 & 36.00 & 64.00 & 1.48 & 54.15 & 2.74 \\
\hline Tryptophan at $100 \mathrm{mgl}^{-1}$ & 10.17 & 78.09 & 16.83 & 12.35 & 680.70 & 30.64 & 39.24 & 60.76 & 1.77 & 57.77 & 2.73 \\
\hline Milagrow at $50 \mathrm{mgl}^{-1}$ & 15.83 & 77.59 & 17.02 & 13.17 & 759.56 & 33.16 & 42.74 & 57.26 & 2.13 & 64.23 & 2.91 \\
\hline Milagrow at $100 \mathrm{mgl}^{-1}$ & 14.98 & 72.38 & 14.77 & 12.73 & 722.15 & 28.87 & 39.89 & 60.11 & 1.62 & 56.11 & 2.81 \\
\hline L.S.D. 0.05 & 4.22 & 3.18 & 1.02 & 3.57 & 118.56 & 3.67 & 1.55 & 1.08 & 0.17 & 3.02 & 0.44 \\
\hline
\end{tabular}




\subsubsection{Fruit chemical compositions}

Data in Table (7) showed that all treatments significantly increased the fruit chemical compositions i.e., nitrogen, phosphorus, potassium, crude protein, total carbohydrates, total soluble solid, total acidity and vitamin $\mathrm{C} \mathrm{mg} 100^{-1} \mathrm{~cm} 3$ juice. From these results could conclude that, the beast treatment was milagrow at $50 \mathrm{mgl}^{-1}$ which recorded the highest values for nitrogen, crude protein, total carbohydrates, total soluble solid and vitamin C. On the contrast, the same treatment was recorded low values for phosphorus, potassium and total acidity comparing with the other treatments during both seasons. Moreover, the results show that, the arginine at $50 \mathrm{mgl}^{-1}$ treatment increased the total acidity (0.44), while it was highly at $25 \mathrm{mgl}^{-1}$, for phosphorus (0.49) and potassium (3.47) in the first season, but, in the second season for total acidity was highest (0.47) at $25 \mathrm{mgl}^{-1}$, but, phosphorus (0.45) and potassium (2.72) with arginine at $50 \mathrm{mgl}^{-1}$, in opposite side, the arginine with $25 \mathrm{mgl}^{-1}$ treatment recorded the low values of the total carbohydrates (60.34), total soluble solid (4.61) $\mathrm{g} 100 \mathrm{~g}^{-1} \mathrm{D}$.Wt. and vitamin C $\mathrm{mg} 100^{-1} \mathrm{~cm} 3$ juice (20.17), especially in the second season compared with other biostimulants.

Table (7): Fruit chemical compositions in tomato fruits as affected by some biostimulants during 2016 and 2017 seasons.

\begin{tabular}{|c|c|c|c|c|c|c|c|c|}
\hline \multirow{2}{*}{ Characteristics } & \multicolumn{7}{|c|}{ g100g ${ }^{-1}$ D.Wt. } & \multirow{2}{*}{$\begin{array}{l}\text { Vitamin C } \\
100 \mathrm{mg}^{-1} \\
\mathrm{~cm}^{-3} \text { juice }\end{array}$} \\
\hline & $\mathrm{N}$ & $P$ & $\mathrm{~K}$ & $\begin{array}{l}\text { Crude } \\
\text { protein }\end{array}$ & $\begin{array}{c}\text { Total } \\
\text { carbohydrates }\end{array}$ & $\begin{array}{c}\text { Total soluble } \\
\text { solids }\end{array}$ & $\begin{array}{c}\text { Total } \\
\text { acidity }\end{array}$ & \\
\hline & \multicolumn{8}{|c|}{ Season 2016} \\
\hline Control & 2.72 & 0.33 & 2.61 & 17.00 & 57.72 & 4.09 & 0.36 & 19.22 \\
\hline Arginine at $25 \mathrm{mgl}^{-1}$ & 2.86 & 0.49 & 3.47 & 17.86 & 61.73 & 4.25 & 0.37 & 20.46 \\
\hline Arginine at $50 \mathrm{mgl}^{-1}$ & 3.16 & 0.36 & 2.40 & 19.75 & 59.52 & 4.18 & 0.44 & 19.33 \\
\hline Tryptophan at $50 \mathrm{mgl}^{-1}$ & 2.91 & 0.33 & 2.65 & 18.19 & 63.54 & 5.24 & 0.38 & 21.14 \\
\hline Tryptophan at $100 \mathrm{mgl}^{-1}$ & 2.95 & 0.33 & 2.83 & 18.44 & 62.19 & 5.17 & 0.40 & 21.80 \\
\hline Milagrow at $50 \mathrm{mgl}^{-1}$ & 3.50 & 0.32 & 2.32 & 21.88 & 66.17 & 5.62 & 0.37 & 22.41 \\
\hline \multirow[t]{2}{*}{ Milagrow at $100 \mathrm{mgl}^{-1}$} & 2.87 & 0.41 & 2.18 & 17.31 & 64.42 & 5.02 & 0.43 & 21.08 \\
\hline & \multicolumn{8}{|c|}{ Season 2017} \\
\hline Control & 2.61 & 0.43 & 2.41 & 16.31 & 58.61 & 5.20 & 0.39 & 20.11 \\
\hline Arginine at $25 \mathrm{mgl}^{-1}$ & 3.46 & 0.36 & 2.62 & 21.63 & 60.34 & 4.61 & 0.47 & 20.17 \\
\hline Arginine at $50 \mathrm{mgl}^{-1}$ & 3.18 & 0.45 & 2.72 & 19.88 & 63.86 & 5.25 & 0.45 & 21.64 \\
\hline Tryptophan at $50 \mathrm{mgl}^{-1}$ & 2.74 & 0.28 & 2.25 & 17.13 & 62.29 & 4.16 & 0.43 & 20.42 \\
\hline Tryptophan at $100 \mathrm{mgl}^{-1}$ & 3.43 & 0.35 & 2.36 & 21.44 & 62.40 & 4.62 & 0.41 & 20.72 \\
\hline Milagrow at $50 \mathrm{mgl}^{-1}$ & 3.71 & 0.30 & 2.13 & 23.19 & 61.89 & 5.43 & 0.41 & 22.15 \\
\hline Milagrow at $\mathrm{mgl}^{-1}$ & 2.83 & 0.32 & 2.20 & 17.69 & 60.81 & 4.47 & 0.45 & 20.81 \\
\hline
\end{tabular}

Finally, from these results we can conclude that, the negative correlation was found among nitrogen, crude protein, total carbohydrates, total soluble solid and vitamin $\mathrm{C}$ with phosphorus, potassium and total acidity. The brassinosteroids inducing growth has been related for increasing in RNA and DNA contents, activity of polymerase, synthesis of protein and sugars as well as starch (Kalinich et al., 1985, Martin-Tanguy, 1997, Vardhini and Rao, 1998, Vasanth et 
al., 2006). Milagrow (Brassinosteroids) has been found for stimulating carbohydrate assimilation and activity of ATP subsequently improving physiological status and directed for increasing fruit yield and quality. It is also evident that they regulate the plant metabolism and yield output.

\section{Conclusions}

Finally, the beast treatment was milagrow at $50 \mathrm{mgl}^{-1}$ for enhancement the anatomical structure and mineral elements transport, as well as photosynthetic rate, subsequently recorded the highest values for early yield $(\mathrm{g})$ plant $^{-1}$ (731.62), total fruits number plant ${ }^{-1}$ (29.74), fruit setting percentage (37.19), total yield $(\mathrm{kg})$ plant $^{-1}$ (1.94), fruit fresh weight fruit ${ }^{-1}(67.38 \mathrm{~g})$ and fruit dry weight fruit $^{-1}(3.14 \mathrm{~g})$, that may be due to enhancing the tomato plant tolerance to adverse conditions especially high temperature during summer season.

\section{References}

A.O.A.C. (2005), Official Methods of Analysis, $18^{\text {th }}$ ed., Association of official agricultural chemists, Washington, DC, USA.

Abd El-Aal, M. M. M. and Eid Rania, S. M. (2018), "Effect of foliar spray with lithovit and amino acids on growth, bioconstituents, anatomical and yield features of soybean plant", $4^{\text {th }}$ International Conference on Biotechnology Applications in Agriculture (ICBAA), Benha
University, Moshtohor and Hurghada, Egypt, pp. 187-201.

Abou Dahab, T. A. M., Abd El-Aziz, N. (2006), "Physiological effect of Diphenylamine and tryptophan on the growth and chemical constituents of Philodendron erubescens plants", World Journal of Agriculture Science, Vol. 2 No. 1, pp. 78-81.

Adil, A. H., Gruda, N. and Geyer, B. (2004), "Effects of temperature and grafting on the growth and development of tomato plants under controlled conditions", In: Rural poverty reduction through research for development and transformation, Berlin, Germany.

Akladious, S. A. and Abbas, S. S. (2013), "Alleviation of sea water stress on tomato plant by foliar application of aspartic acid and glutathione", Bangladesh Journal of Botany, Vol. 42 No. 1, pp. 31-43.

Arteca, R. N., Tsai, D. S., Schlagnhaufer, C., Mandava, N.B. (1983), "The effect ofbrassinosteroid on auxininduced ethylene production by etiolated mung bean segments", Physiologia Plantarum, Vol. 59, pp. 539-544, 1983.

Attia, A. N. E., Badawi, M. A., Seadh, S. E. and El-Hety, S. M. S. (2011), "Response of growth and petal yield of safflower to sowing dates, nitrogen fertilizer, levels and times of foliar application with natural 
growth promoters "Melagrow"", Mansoura Journal of Plant Production, Vol. 2 No. 2, pp. 17031716.

Bajguz, A. and Hayat, S. (2009), "Effects of brassinosteroids on the plant responses to environmental stresses", Plant Physiology and Biochemistry, Vol. 47, pp. 1-8.

Braun, P. and Wild, A. (1984), "The influence of brassinosteroid on growth and parameters of photosynthesis of wheat and mustard plants", Journal of Plant Physiology, Vol. 49, pp. 427-451.

Cerana, R., Bonetti, A., Marre, M. T., Romani, G. and Lado, P. (1983), "Effects of a brassinosteroid on growth and electrogenic proton extrusion in Azuki bean epicotyls (Vigna angularis)", Physiologia Plantarum, Vol. 59, pp. 23-27.

Chen, H., Mc Carig, B., Melotto, M., Yang, A., He, S. and Howe, G. A. (2004), "Regulation of plant arginase by wounding, jasmonate and the phytotoxin coronatine", Journal of Biological Chemistry, Vol. 279, pp. 45998-46007.

Clouse, S. D. (1996), "Molecular genetic studies confirm the role of brassinosteroids in plant growth and development", The Plant Journal, Vol. 10 No. 1, pp. 1-8.

Clouse, S. D. and Zurek, D. (1991), Molecular analysis of brassinolide action in plant growth and development. In: Cutler, H. G., Yokota, T., Adam, G. (eds.), Brassinosteroids, ACS Symposium Series, Vol. 474, American Chemical Society, USA.

Divi, U. and Krishna, P. (2009), "Brassinosteroids confer stress tolerance", Hirt, H. (ed.), Plant stress biology: genomics goes systems biology, Wiley-VCH Verlag $\mathrm{GmbH}$ \& Co. KGaA, Weinhein, Germany, pp. 119-135.

El-Badawy, H. E. M. and Abd El-Aal, M. M. M. (2013), "Physiological response of keitt mango (Mangifera indica L.) to kinetin and tryptophan", Journal of Applied Sciences Research, Vol. 9 No. 8, pp. 4617-4626.

El-Bassiouny, H. M. S., Mostafa, H. A., El-Khawas, S. A., Hassanein, R. A., Khalil, S. I. and Abd El-Monem, A. A. (2008), "Physiological responses of wheat plant to foliar treatments with arginine or putrescine", Australian Journal of Basic and Applied Sciences, Vol. 2, pp. 13901403.

El-Desouky, S. A., Ismaeil, F. H., Wanas, A. L., Fathy, S. L. and Abd El-All, M. M. (2011), "Effect of yeast extract, amino acids and citric acid on physio-anatomical aspects and productivity of tomato plants grown in late summer season", Minufiya Journal of Agricultural Research, Vol. 36, pp. 859-884. 
Evans, T. P. and Malmberg, R. L. (1989), "Do polyamines have roles in plant development?", Annual Review of Plant Physiology and Plant Molecular Biology, Vol. 40, pp. 235.

Gabr, M. A., Fathi, M. A., Mohamed, A. I. and Mckhaeil, G. B. (2011), "Influences of some chemical substances used to induce early harvest of 'Canino' apricot trees", Nature and Science, Vol. 9 No. 8, pp. 59-65.

Gioseffi, E., Neergaard, A. and Schjoerring, J. K. (2012), "Interactions between uptake of amino acids and inorganic nitrogen in wheat plants", Biogeosciences, Vol. 9, pp. 1509-1518.

Gomes, M. M. A., Campostini, E., Leal, N. R., Viana, A. P., Ferraz, T. M., Siqueira, L. N., Rosa, R. C. C., Netto, A. T., Nunez Vazquez, M. and Zullo, M. A. T. (2006), "Brassinosteroid analogue effect on the yield of yellow passion fruit plants", Scientia Horticulturae, Vol. 110, pp. 235-240.

Hassanein, R. A., Khalil, S. I., ElBassiouny, H. M. S., Mostafa, H. A. M., El-Khawas, S. A. and Abd ElMonem, A. A. (2008), "Protective role of exogenous arginine or putrescine treatments on heat shocked wheat plant", In: $1^{\text {st }}$ International Conference on Biological and Environmental Sciences, Hurghada, Egypt.
Hayat, S. and Ahmad, A., Fariduddin, Q, (2003), "Brassinosteroids: A Regulator of $21^{\text {st }}$ Century". Hayat $\mathrm{S}$, Ahmad A (eds.), Brassinosteroids, Springer, Netherlands, pp. 231-246.

Hayat, S., Ahmad, A., Mobin, M., Hussain, A. and Fariduddin, Q. (2000), "Photosynthetic rate,growth and yield of mustard plants sprayed with 28-homobrassinolide", Photosynthetica, Vol. 38, pp. 469471.

He, L., Nada, K. and Tachibana, S. (2002), "Effects of Spd pretreatment through the roots on growth and photosynthesis of chilled cucumber plants (Cucumis sativus L.)", Journal of the Japanese Society for Horticultural Science, Vol. 71, pp. 490-498.

Helal, S. H. M. and Gomaa Elham, F. (2007), "Response of Egyptian lupine plant to treatment with stigmasterol", Mansoura University Journal of Agricultural Sciences, Vol. 32 No. 10, pp. 8315-8331.

Hussein, M. M., Faham, S. Y., Alva, A. K. (2014), "Role of foliar application of nicotinic acid and tryptophan on onion plants response to salinity stress", Journal of Agricultural Science, Vol. 6 No. 8, pp. 41-51.

Iwasaki, T. and Shibaoka, H. (1991), "Brassinosteroids act as regulators of tracheary-element differentiation in isolated Zinnia mesophyll cells", 
Plant Cell and Physiology, Vol. 32, pp. 1007-1014.

Johanson, D. V. (1940), Plant microtechnique, McGrow-Hill Book Co. Inc., New York, London, pp. 27-154.

Kalinich, J. F., Mandava, N. B. and Todhunter, J. A. (1985), "Relationship of nucleic acid metabolism to brassinolide-induced responses in beans", Journal of Plant Physiology, Vol. 120, pp. 207-214.

Katsumi, M. (1985), "Interaction of a brassinosteroid with IAA and $\mathrm{GA}_{3}$ in the elongation of cucumber hypocotyl sections", Plant Cell and Physiology, Vol. 26, pp. 615-625.

Khalil, S. I., El-Bassiouny, H. M. S., Hassanein, R. A., Mostafa, H. A. M., El-Khawas, S. A. and Abd ElMonem, A. A. (2009), "Antioxidant defense system in heat shocked wheat plants previously treated with arginine or putrescine", Australian Journal of Basic and Applied Sciences, Vol. 3 No. 3, pp. 15171526.

Koshioka, M., Harda, J., Noma, M., Sassa, T., Ogiama, K., Taylor, J. S., Rood, S. B., Legge, R. L. and Pharis, R. P. (1983), "Reversed phase $\mathrm{C}_{18}$ high performance liquid chromatography of acidic and conjugated gibbberellins", Journal of Chromatography A, Vol. 256, pp.101-115.
Liu, J. H., Nada, K., Honda, C., Kitashiba, H. and Wen, X. P. (2006), "Polyamine biosynthesis of apple callus under salt stress. Importance of the arginine decarboxylase pathway in stress responses", Journal of Experimental Botany, Vol. 57, pp. 2589-2599.

Liu, X., Wang, L., Liying, L., Yangdong, G. and Huazhong, R. (2011), "Alleviating effect of exogenous nitric oxide in cucumber seedling against chilling stress", African Journal of Biotechnology, Vol. 10, pp. 4380-4386.

Mandava, N. B. (1988), "Plant growthpromoting brassinosteroids", Annual Review of Plant Physiology and Plant Molecular Biology, Vol. 39, pp. 23-52, 1988.

Martin-Tanguy, J. (1997), "Conjugated polyamines and reproductive development: biochemical, molecular and physiological approaches", Physiologia Plantarum, Vol. 100, pp. 675-688.

Mayumi, K. and Shibaoka, H. A. (1995), "Possible double role of brassinolide in the reorientation of cortical microtubules in the epidermal cells of Azuki bean epicotyls", Plant Cell and Physiology, Vol. 36, pp.173181.

Mitchell, J., Mandava, N., Worley, J., Plimmer, J. and Smith, M. (1970), "Brassins - a new family of plant hormones from rape pollen", Nature, 
Vol. 225, pp. 1065-1066.

Mostafa, H. A. M., Hassanein, R. A., Khalil, S. I., El-Khawas, S. A., ElBassiouny, H. M. S. and Abd ElMonem, A. A. (2009), "Effect of arginine or putrescine on growth, yield and yield components of late sowing wheat", International Journal of Applied Sciences Research, Vol. 11, pp. 27-36.

Nasibi, F., Yaghoobi, M. and Kalantari, K. H. (2011), "Effect of exogenous arginine on alleviation of oxidative damage in tomato plant under water stress", Journal of Plant Interactions, Vol. 6, pp. 291-296.

Nassar, A. H., El-Tarabily, K. A. and Sivasithamparam, K. (2003), "Growth promotion of bean (Phaseolus vulgaris L.) by a polyamine-producing isolate of Streptomyces griseoluteus", Plant Growth Regulation, Vol. 40 No. 2, pp. 97-106.

Neill, S., Desikan, R. and Hancock, J. T. (2003), "Nitric oxide signaling in plants", New Phytologist, Vol. 159, pp.11-35.

Nicander, B. U., Bjorkman, P. and Tillberg, E. (1993), "Immyno affinity co-purification of cytokinins and analysis by high-performance liquid chromatography with ultra violet spectrum detection", Planta, Vol. 189, pp. 312-320.

Orabi, S. A., Talaat, I. M. and Balbaa, L.
K. (2014), "Physiological and biochemical responses of thyme plants to some antioxidants", Bioscience, Vol. 6 No. 2, pp. 118 125.

Paschalidis, A. K. and RoubelakisAngelakis, A. K. (2005), "Sites and regulation of polyamine catabolism in the tobacco plant. Correlation with cell division/expansion, cell cycle progression and vascular development", Plant Physiology, Vol. 138, pp. 2174-2184.

Patton, A. J., Cunningham, S. M., Volenec, J. J. and Reicher, Z. J. (2007), "Differences in freeze tolerance of zoysia grasses II carbohydrates and proline", Crop Science, Vol. 47, pp. 2170-2181.

Pelt, R. S. V. and Popham, T. W. (2006), "Substituted tertiary amine plant bioregulators affect yield and pigment content of Paprika", Journal of Vegetation Science, Vol. 1 No. 3, pp. 63-71.

Pressman, E., Peet, M. M. and Pharr, D. M. (2002), "The effect of heat stress on tomato pollen characteristics is associated with changes in carbohydrate concentration in the developing anthers", Annals of Botany, Vol. 90, pp. 631-636.

Rai, V. K. (2002), "Role of amino acid in plant responses to stresses", Biologia Plantarum, Vol. 45, pp. 481-487.

Saeed, A., Hayat, K., Khan, A. A. and 
Iqbal, S. (2007), "Heat tolerance studies in tomato (Lycopersicon esculentum Mill.)", International Journal of Agriculture \& Biology, Vol. 9 No. 4, pp. 649-652.

Salazar, S. M., Coll, Y., Viejobueno, J. and Coll, F. (2016), "Response of strawberry plants to the application of brassinosteroid under field conditions", Rev. Agron. Noroeste Argent., Vol. 36 No. 1, pp. 37-41

Sass, J. E. (1951), Botanical microtechnique, Iowa State University Press, Ames, Iowa, pp. 228.

Sasse, J. M. (1990), "Brassinolide induced elongation and auxin", Physiologia Plantarum, Vol. 80, pp. 401-408.

Sato S., Kamiyama, M., Iwata, T., Makita, N., Furukawa, H. and Ikeda, H. (2006), "Moderate increase of mean daily temperature adversely affects fruit set of Lycopersicon esculentum by disrupting specific physiological processes in male reproductive development", Annals of Botany, Vol. 97, pp. 731-738.

Seadh, S. E., Attia, A. N. E., Badawi, M. A. and El-Hety, S. M. S. (2012), "Response of seed yield and its components of safflower to sowing dates, nitrogen fertilizer, levels and times of foliar application with milagrow", Journal of Biological Sciences, Vol. 12 No. 6, pp. 342348.
Snedecor, G. W. and Cochran, W. G. (1980), Statistical methods, $7^{\text {th }}$ Ed., Iowa State University Press, Ames, Iowa, USA.

Song, J. K., Nada, M. and Tachibana, S. (1999), "Ameliorative effect of polyamines on high temperature inhibition of in vitro pollen germination in tomato (Lycopersicon esculentum Mill.)", Scientia Horticulturae, Vol. 80, pp. 203-212.

Symons, G. M., Davies, C., Shavrukov, Y., Dry, I. B., Reid, J. B. and Thomas, M. R. (2006), "Grapes in steroids. Brassionsteroid are involved in grape berry ripening", Plant Physiology, Vol. 140 No. 1, pp. $150-158$.

Vardhini, B. V. and Rao S. S. R. (1998), "Effect of brassinosteroids on growth, metabolit content and yield of Arachis hypogaea", Phytochemistery, Vol. 48, pp. 927930.

Vasanth, K., Lakshmiprabha, L. and Jayabalan, N. (2006), "Amino acids enhancing plant regeneration from cotyledon and embryonal axis of peanut (Arachis hypogaea L.)", Indian Journal of Crop Science, Vol. 1, pp. 79-83.

Vollenweider, P. and Gunthardt-Goerg, M. S. (2005), "Diagnosis of abiotic and biotic stress factors using the visible symptoms in foliage", Environmental Pollution, Vol. 137, 
pp. 455-465.

Walters, D. R. (2000), "Polyamines in plant-microbe interactions", Physiological and Molecular Plant Pathology, Vol. 57, pp. 137-146.

Wettestein, D. V. (1957), "ChlorophyllLtale and der submikro skopische from weckses der plastiden", Experimental Cell Research, Vol. 12, pp. 427-433.

Wilcox, J., Catignani, G. and Lazarus, C. (2003), "Tomatoes and cardiovascular health", Critical Reviews in Food Science and Nutrition, Vol. 43 No. 1, pp. 1-18.

Yokota, T. and Takahashi, N. (1985), "Chemistry, physiology and agricultural application of brassinolide and related steroids", In: BOPP, M. (Ed.), Plant Growth Substances, Springer-Verlag, Berlin, Germany, pp. 129-138.

Yokota, T. (1997), "The structure, biosynthesis and function of brassinosteroids", Trends in Plant Sciences, Vol. 2, pp. 137-143.
Zeid, I. M. (2009), "Effect of arginine and urea on polyamines content and growth of bean under salinity stress", Acta Physiologiae Plantarum, Vol. 31, pp. 65-70.

Zhang, S., Jiang, H., Peng, S., Korpelainen, H. and Li, C. (2011), "Sex related differences in morphological, physiological, and ultra structural responses of Populus cathayana to chilling", Journal of Experimental Botany, Vol. 62, pp. 675-686.

Zurek, D. M., Rayle, D. L., McMorris, T. C. and Clouse, S. D. (1994), "Investigation of geneexperssion, growth kinetics, and wall extensibility during brassinoesteroid-regulated stem elongation", Plant Physiology, Vol. 104, pp. 505-513. 